\title{
AN INVESTIGATION OF THE MECHANICAL PROPERTIES OF SINTERED FLY ASH LIGHTWEIGHT AGGREGATE CONCRETE (SFLWAC) WITH STEEL FIBERS
}

\author{
B.RANJITH BABU ${ }^{1}$, R.THENMOZHI ${ }^{2}$
}

\begin{abstract}
: this study investigates the fresh and mechanical performance of concrete incorporating sintered fly ash lightweight aggregates (SFLWA) both with and without steel fibers. Comparative assessments of natural aggregates with sintered fly ash aggregates were evaluated. Mix design was obtained by the IS method for M30 grade concrete, and within the natural aggregates were replaced with $20 \%, 40 \%$, and $60 \%$ amounts of SFLWA. The addition of SFLWA shows an increase in the workability of the concrete. Replacement with SFLWA increases with an increase in slump value, and decreases in strength parameters. Compressive strength of $42.6 \mathrm{MPa}$ was achieved with a $40 \%$ replacement of SFLWA with steel fibers. The mechanical properties such as compressive strength, split tensile strength, flexural strength, elastic modulus, and structural efficiency of SFLWAC were examined, both with and without fibers. The incorporation of fibers drastically improved the mechanical properties of the mix.
\end{abstract}

Keywords: Sintered fly ash aggregates, slump, compressive strength, split tensile strength, flexural strength, elastic modulus, structural efficiency

\section{INTRODUCTION}

India delivers around 120 million tons of fly ash yearly. The absence of reasonable innovation and nonattendance of the market have deterred Indian business visionaries from delivering sintered fly ash aggregates. Fly ash-based artificial lightweight aggregates offer potential for wide range use in

\footnotetext{
${ }^{1}$ Assistant Professor., M.E., P.S.N.A. College of Engineering and Technology, Faculty of Civil Engineering, Dindigul624622, Tamil Nadu, India, e-mail: ranjithbabucivil@psnacet.edu.in.

${ }^{2}$ Associate Professor., M.E., Ph.D., Government College of Technology, Faculty of Civil Engineering, Coimbatore641013, Tamil Nadu, India, e-mail: drthenmozhi@gct.ac.in.
} 
the construction industry. Apart from utilizing it in solid industry as a cement replacement, fly ash uses in other related enterprises have been, for example, exploited in cell concrete, pre-assembled products, and road development. However, around $75 \%$ of fly ash remains unutilized. Concrete compounded with lightweight aggregates (LWAs) has been used successfully for structural purposes since the second half of the twentieth century, and has become a very satisfactory alternative, when compared with conventional concrete. Expanded clay and sintered fly ash, which are commercially light weight aggregates, are acquired through heat treatment in temperatures of 1000 to $1200^{\circ} \mathrm{C}$ [1]. Sintering is a technique for making aggregates from powder by heating the material in a sintering furnace below its liquefying point (solid state sintering) until its particles adhere to each other. Sintering is customarily utilized for producing earthenware protests, and has likewise discovered uses in such fields as powder metallurgy. Sintering is compelling when the process decreases the porosity and improves properties, for example, quality, translucency, and thermal conductivity; yet, in different cases, it might be helpful to build its quality, yet keep its gas permeability consistent. During the firing process and as it continues; grain size becomes smaller and more spherical because the particle's surface tends to flow into the pores within based on the difference between vapor-pressure and the cross-sectional area of the pore's neck [2]. LWC can be made with compressive strength ranging from 30 to $80 \mathrm{MPa}$ and can without much effort be made while by utilizing such aggregates, while LWC with compressive strength ranging from 20 to $50 \mathrm{MPa}$ might be basically produced $[3,4]$. The expanding uses of LWC have brought about a requirement for artificial lightweight aggregate generation which could be accomplished by the sintering process. Also, utilizing fly ash in the generation of lightweight aggregates diminishes the natural harm. Mix design methodology for conventional aggregate concrete has a deterministic technique to acquire a required strength and workability. Lightweight concrete mix design is represented by a careful mix design technique, as the aggregates are naturally permeable with requires an underlying immersion, and further increment the water demand for acquire the desirable workability $[5,6]$. Compressive properties of concrete were influenced with increments of aggregates, and, in addition, sort of aggregates were utilized as a part of the concrete mix. Sintered fly ash aggregates show higher compressive strength compared to cold bonded fly ash aggregates [7]. The expansion of the fibers into concrete is another strategy helping to improve building properties of concrete. The most helpful upgrade is directed to the flexural capacity, toughness, post-failure ductility, and crack control [8]. The fibers can be made from either natural materials (asbestos, sisal, and cellulose) or a manufactured product (glass, steel, carbon, and polymers). Steel is the most commonly used type among the various fibers for most structural and non-structural purposes [9]. A systematic study was undertaken on natural aggregates with sintered 
fly ash aggregate as: (i) Crushing Strength and Impact Test (ii) Replacement of SFLWA of 20\%, $40 \%$, and $60 \%$, for Compressive strength, Split Tensile strength, Flexural strength, and stress-strain behaviour of SFLWAC with and without steel fibers.

\section{MATERIALS USED}

In this experimental program, ordinary grade 53 Portland cement [10] was used as a binding material in the concrete with a specific gravity of 3.15 and fineness [11] of $4 \%$. This cement was obtained from Coimbatore, a local supplier. The 7 and 28 day compressive strength of the cement was 34.45 $\mathrm{MPa}$ and $51.41 \mathrm{MPa}$, respectively. Locally available river sand was used as a fine aggregate in the concrete mix with a specific gravity of 2.65 and a fineness of modulus of 2.54 . The maximum nominal grain size of this fine aggregate was $4.75 \mathrm{~mm}$. Two types of coarse aggregates were used in the concrete mix; one is a natural aggregate and the other is sintered fly ash aggregate (Fig.1). The natural aggregates were procured from local suppliers in Coimbatore and the sintered fly ash aggregates were supplied by GBC India private limited, Gujarat. The sintered aggregate is a fly ash-based aggregate and it is manufactured by the sintering process. The sieve analysis of the natural and sintered fly ash aggregates is shown in Table 1. Mechanical properties of natural aggregates and SFLWA were obtained from the crushing strength and impact test. A sample consisting of particle sizes passing through a $12.5 \mathrm{~mm}$ sieve and retained on a $10 \mathrm{~mm}$ sieve size was taken. These tests were conducted as per standard procedure, given in IS code [12]. The surface of the aggregates is levelled in a 150 $\mathrm{mm}$ diameter open-ended steel cylinder, the plunger is inserted, and then placed in the compression testing machine loaded at a uniform rate, so as to achieve a 40 ton load in 10 minutes. Afterwards, the load is released. The crushing strength was determined from the weight fraction of a sample passing through a $2.36 \mathrm{~mm}$ sieve to the total weight of aggregate sample used. Similarly, the impact testing machine was placed on a levelled surface with a rigid base, and the test consisted of releasing the hammer suddenly from a height of $380 \mathrm{~mm}$, with a total number of 15 blows given. The impact test was determined from the weight fraction of a sample passing through a $2.36 \mathrm{~mm}$ sieve to the total weight of aggregate sample used. The mechanical properties of both the natural and sintered fly ash aggregates are given in Table 2. Loose hook-ended and low carbon steel fibers with an aspect ratio of 55 , a length of $30 \mathrm{~mm}$, and diameter of $0.55 \mathrm{~mm}$. The tensile strength of these loose hook-ended fibers was $1450 \mathrm{MPa}$. Conplast SP430, a sulphonated naphthalene polymer-based super Plasticizer was used to produce the SFLWAC mixtures. Potable water collected from the laboratory water supply system has been used for all the mixes. 


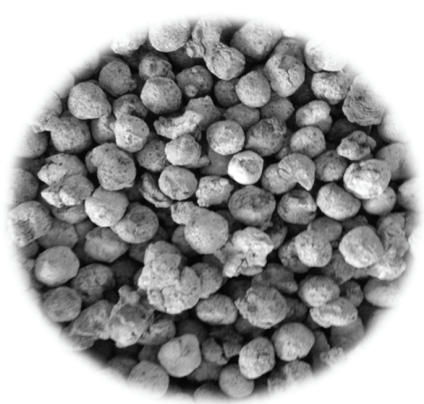

Fig.1. Sintered fly ash aggregate

Table 1. Sieve analysis results of the natural and sintered fly ash aggregates

\begin{tabular}{|c|c|c|c|}
\hline \multirow{3}{*}{ Aggregate Type } & $\begin{array}{c}\text { Sieve Size } \\
(\mathrm{mm})\end{array}$ & $\begin{array}{c}\text { Cumulative Percentage Weight retained } \\
(\%)\end{array}$ & $\begin{array}{c}\text { Percentage } \\
\text { Passing } \\
(\%)\end{array}$ \\
\hline \multirow{5}{*}{ Natural Aggregate } & $20 \mathrm{~mm}$ & 0 & 100 \\
\cline { 2 - 4 } & $16 \mathrm{~mm}$ & 2.5 & 98 \\
\cline { 2 - 4 } & $12.5 \mathrm{~mm}$ & 28.1 & 72 \\
\cline { 2 - 4 } & $10 \mathrm{~mm}$ & 71.8 & 28 \\
\cline { 2 - 4 } & $4.75 \mathrm{~mm}$ & 99.9 & 0 \\
\hline \multirow{5}{*}{ Sintered Fly Ash Aggregate } & PAN & 100 & 100 \\
\cline { 2 - 4 } & $20 \mathrm{~mm}$ & 0 & 95 \\
\cline { 2 - 4 } & $16 \mathrm{~mm}$ & 4.7 & 37 \\
\cline { 2 - 4 } & $12.5 \mathrm{~mm}$ & 24.9 & 1 \\
\cline { 2 - 4 } & $4.75 \mathrm{~mm}$ & 62.7 & 0 \\
\cline { 2 - 4 } & PAN & 98.9 & 100 \\
\hline
\end{tabular}

Table 2. Physical and mechanical properties of natural and sintered fly ash aggregates

\begin{tabular}{|c|c|c|}
\hline Physical and mechanical properties & Natural aggregate & Sintered fly ash aggregate \\
\hline Specific gravity (saturated surface dry) & 2.65 & 1.395 \\
\hline Water absorption for $24 \mathrm{~h}(\%)$ & 0.9 & 16.8 \\
\hline Loose bulk density $\left(\mathrm{kg} / \mathrm{m}^{3}\right)$ & 1490 & 830 \\
\hline Rodded bulk density $\left(\mathrm{kg} / \mathrm{m}^{3}\right)$ & 1626 & 895 \\
\hline Fineness modulus & 2.02 & 1.91 \\
\hline Aggregate impact value (\%) & 19.42 & 27.78 \\
\hline Aggregate crushing strength (\%) & 12.77 & 15.63 \\
\hline
\end{tabular}




\section{MIX PROPORTIONS}

In this study, concrete mixtures were designed for a target strength of M30 grade with a high workability [13]. The water-cement ratio has been kept as 0.35 . About $2 \%$ of the super plasticizer was used in the mixes to attain workability. The proportioning and descriptions of the concrete mixtures are summarized in Table 3.

Table 3. Mix proportions

\begin{tabular}{|c|c|c|c|c|c|c|c|c|}
\hline MIX ID & $\begin{array}{c}\text { Cement } \\
\text { Content } \\
\left(\mathrm{kg} / \mathrm{m}^{3}\right)\end{array}$ & $\begin{array}{c}\text { Fine aggregate } \\
\left(\mathrm{kg} / \mathrm{m}^{3}\right)\end{array}$ & $\begin{array}{c}\text { Coarse } \\
\text { aggregate } \\
\left(\mathrm{kg} / \mathrm{m}^{3}\right)\end{array}$ & $\begin{array}{c}\text { Sintered fly ash } \\
\text { aggregate } \\
\left(\mathrm{kg} / \mathrm{m}^{3}\right)\end{array}$ & $\begin{array}{c}\text { Water } \\
\text { content } \\
\left(\mathrm{kg} / \mathrm{m}^{3}\right)\end{array}$ & $\begin{array}{c}\text { w/c } \\
\text { ratio }\end{array}$ & $\begin{array}{c}\text { SP } \\
(\%)\end{array}$ & $\begin{array}{c}\mathrm{V}_{\mathrm{f}} \\
(\%)\end{array}$ \\
\hline CC & 435 & 891.5 & 969 & 0 & 152.4 & 0.35 & 2.0 & 0 \\
\hline SFLWAC1 & 435 & 891.5 & 776 & 194 & 152.4 & 0.35 & 2.0 & 0 \\
\hline SFLWAC2 & 435 & 891.5 & 582 & 388 & 152.4 & 0.35 & 2.0 & 0 \\
\hline SFLWAC3 & 435 & 891.5 & 435 & 535 & 152.4 & 0.35 & 2.0 & 0 \\
\hline SFLWAC4 & 435 & 891.5 & 969 & 0 & 152.4 & 0.35 & 2.0 & 0.5 \\
\hline SFLWAC5 & 435 & 891.5 & 776 & 194 & 152.4 & 0.35 & 2.0 & 0.5 \\
\hline SFLWAC6 & 435 & 891.5 & 582 & 388 & 152.4 & 0.35 & 2.0 & 0.5 \\
\hline SFLWAC7 & 435 & 891.5 & 435 & 535 & 152.4 & 0.35 & 2.0 & 0.5 \\
\hline
\end{tabular}

Notes: w/c ratio - water to cement ratio; SP-Super Plasticizer; $\mathrm{V}_{\mathrm{f}}-$ Volume of Steel fibers; CC- Control Concrete; SFLWCA1- Sintered fly ash lightweight aggregate concrete mixture 1

\section{CASTING AND CURING OF CONCRETE SPECIMENS}

Concrete production using sintered fly ash lightweight aggregates requires careful estimates of the water content. Therefore additional water was required to achieve the desired workability level due to the consumption of water for the saturation of pores in the aggregates. This initial wetting of the sintered fly ash aggregates in water, which were later air dried for $30 \mathrm{~min}$, ensures an initially saturated surface's dry conditions. Concrete mix was prepared in a laboratory drum mixer with dry ingredients like cement, fine aggregate, and pre-soaked sintered fly ash. After homogenizing the aggregates and the binder (after 30 seconds of mixing) about a third of the mixing water was added slowly into the mixer and mixing continued for an additional minute. Finally, the superplasticizer (along with the remaining water) was introduced, and the concrete was mixed for 3 minutes and then left to sit for an additional 2 minutes. Afterwards, all the materials were mixed again for 2 more minutes to complete the mixing sequence. In addition, to improve the bond strength of the sintered fly ash aggregates, steel fibers were added during casting. The fresh concrete was then cast into 100 $\mathrm{mm}$ sized cubes and $100 \mathrm{~mm} \times 200 \mathrm{~mm}$ cylindrical specimens for an estimate of their mechanical strength properties after 28 days of normal water curing. Flexural strength tests were also performed on $100 \times 100 \times 500 \mathrm{~mm}$ prismatic specimens according to the standard testing method [14]. In total, 
24 concrete cube specimens, 40 cylindrical specimens, and 24 prismatic specimens were cast and tested across 8 different concrete mixtures.

\section{RESULTS AND DISCUSSION}

\subsection{SLUMP AND UNIT WEIGHT OF CONCRETE}

Slump [15] and unit weight test results of 8 different concrete mixes are shown in Table 4. As shown in this table, the slump values of the concretes vary between $76 \mathrm{~mm}$ and $205 \mathrm{~mm}$. The mixtures containing without steel fibers show that the slump value is increasing as the SFLWA content increases. The addition of steel fibers decreases the slump and increases the unit weight of the concrete mixtures.

Table 4. Slump values and unit weights of concrete mixtures

\begin{tabular}{|c|c|c|}
\hline MIX ID & Slump Value $^{\mathrm{a}}(\mathrm{mm})$ & Unit weight $^{\mathrm{b}}\left(\mathrm{kg} / \mathrm{m}^{3}\right)$ \\
\hline CC & 100 & 2422 \\
\hline SFLWAC1 & 140 & 2297 \\
\hline SFLWAC2 & 175 & 2110 \\
\hline SFLWAC3 & 205 & 2093 \\
\hline SFLWAC4 & 76 & 2434 \\
\hline SFLWAC5 & 82 & 2356 \\
\hline SFLWAC6 & 87 & 2267 \\
\hline SFLWAC7 & 94 & 2198 \\
\hline $\begin{array}{l}\text { CC- Control Concrete; SFLWCA1- Sintered Fly ash lightweight aggregate concrete mixture1; }{ }^{\text {a }} \text { Tested Values by } \\
\text { using slump cone; }{ }^{\text {T }} \text { Tested Values by using Density Buket. }\end{array}$ \\
\hline
\end{tabular}

\subsection{COMPRESSIVE STRENGTH}

The 28-day compressive strength values of the SFLWACs are given in Table 5. Compressive strength of the control concrete was 32.1 MPa [13]. Mixtures SFLWAC1, SFLWAC2, and SFLWAC3 indicate the compressive strength results without the addition of steel fibers. Among these, SFLWAC2 shows better results. This indicates the optimum percentage of sintered fly ash aggregate for the concrete mix. Mixtures SFLWAC5, SFLWAC6, and SFLWAC7 indicate the compressive strength results of SFLWAC with steel fibers. SFLWAC6 shows a higher compressive strength (42.6 $\mathrm{MPa}$ ) than all the mixtures. The relative compressive strength values of SFLWACs are also given in Table 5. It can be seen from the results that compressive strengths of SFLWACs are higher by about 4-32\% than the control mixture. From the observed results for compressive strength on the cubes, the highest strength was achieved by SFLWAC6 manufactured with $40 \%$ of sintered fly ash 
aggregates with steel fibers. While the control concrete exhibits the lowest compressive strength, 32.1 $\mathrm{MPa}$, the average compressive strength of SFLWAC6 $32 \%$ increased.

\subsection{SPLIT TENSILE STRENGTH}

The 28-day split tensile strength values of SFLWACs are given in Table 5. The split tensile strength of the control concrete was 2.69 MPa [13]. Mixtures SFLWAC1, SFLWAC2, and SFLWAC3 indicate the split tensile strength results without the addition of steel fibers. Among these, SFLWAC2 shows better results. This indicates the optimum percentage of sintered fly ash aggregates for concrete. Mixtures SFLWAC5, SFLWAC6, and SFLWAC7 indicate the split tensile strength results of SFLWAC with steel fibers. SFLWAC5 shows a higher split tensile strength (5.124 MPa) than all the mixtures. The relative split tensile strength values of SFLWACs are also given in Table 5. It can be seen from the results that the split tensile strengths of SFLWACs are higher by about $4-90 \%$ than the control mixture. From the observed results for split tensile strength on the cylinders, the highest strength was achieved by SFLWAC5 manufactured with $20 \%$ of sintered fly ash aggregates with steel fibers. While the control concrete exhibits the lowest compressive strength, 2.69 MPa, the average split tensile strength of SFLWAC5 $90 \%$ increased.

\subsection{FLEXURAL STRENGTH}

The 28-day flexural strength values of SFLWACs are given in Table 5. The flexural strength of the control concrete was 7.68 MPa [13]. Mixtures SFLWAC1, SFLWAC2, and SFLWAC3 indicate the flexural strength results without the addition of steel fibers. Among these, SFLWAC2 shows better results. This indicates the optimum percentage of sintered fly ash aggregates for concrete. Mixtures SFLWAC5, SFLWAC6, and SFLWAC7 indicate the flexural strength results of SFLWAC with steel fibers. SFLWAC5 shows a higher flexural strength $(8.23 \mathrm{MPa})$ than all the mixtures. The relative flexural strength values of SFLWACs are also given in Table 5. It can be seen from the results that flexural strengths of SFLWACs decrease about 6-17 \% comparing to the control mixture. From the observed results for flexural strength of the beams, the highest strength was achieved by SFLWAC5 manufactured with $20 \%$ sintered fly ash aggregates with steel fibers. While the control concrete exhibits the lowest flexural strength, $7.68 \mathrm{MPa}$, the average flexural strength of SFLWAC5 $7 \%$ increased. 
Table5. Mechanical properties of SFLWAC mixtures

\begin{tabular}{|c|c|c|c|c|c|c|}
\hline MIX ID & $\begin{array}{c}\text { Compressive } \\
\text { strength }^{\text {a }} \\
(\mathrm{MPa})\end{array}$ & $\begin{array}{c}\text { Relative } \\
\text { Compressive } \\
\text { strength (\%) }\end{array}$ & $\begin{array}{c}\text { Split Tensile } \\
\text { strength }^{\text {a }} \\
(\mathrm{MPa})\end{array}$ & $\begin{array}{c}\text { Relative Split } \\
\text { Tensile } \\
\text { strength (\%) }\end{array}$ & $\begin{array}{c}\text { Flexural } \\
\text { strength }^{\text {a }} \\
(\mathrm{MPa})\end{array}$ & $\begin{array}{c}\text { Relative } \\
\text { Flexural } \\
\text { strength (\%) }\end{array}$ \\
\hline CC & 32.1 & 100 & 2.69 & 100 & 7.68 & 100 \\
\hline SFLWAC1 & 34.40 & 107 & 2.80 & 104 & 6.25 & 81 \\
\hline SFLWAC2 & 40.93 & 127 & 3.92 & 145 & 7.25 & 94 \\
\hline SFLWAC3 & 35.73 & 111 & 3.09 & 114 & 6.40 & 83 \\
\hline SFLWAC4 & 33.5 & 104 & 3.91 & 145 & 7.85 & 102 \\
\hline SFLWAC5 & 35.3 & 110 & 5.12 & 190 & 8.23 & 107 \\
\hline SFLWAC6 & 42.6 & 132 & 4.61 & 171 & 7.31 & 95 \\
\hline SFLWAC7 & 39.2 & 122 & 4.04 & 150 & 7.26 & 94 \\
\hline aTested values are average of 3 specimens
\end{tabular}

\subsection{ELASTIC MODULUS OF SFLWAC MIXTURES}

The 28-day elastic modulus of the control concrete was $20.18 \mathrm{GPa}[14]$. Mixtures SFLWAC1, SFLWAC2, and SFLWAC3 indicate the elastic modulus results without the addition of steel fibers. Among these, SFLWAC3 shows better results. This indicates the optimum percentage of sintered fly ash aggregates for concrete. Mixtures SFLWAC5, SFLWAC6, and SFLWAC7 indicate the elastic modulus results of sintered fly ash lightweight aggregate concrete (SFLWAC) with steel fibers. Mixture SFLWAC7's elastic modulus was $45.74 \mathrm{GPa}$, which is less than that of SFLWAC3. The elastic modulus values of the SFLWACs mixtures are given in Table 6. It can be seen from the results that the elastic modulus of the SFLWACs increases about $63-228 \%$ over the control mixture. The SFLWAC mixtures with the addition of $0.5 \%$ steel fibers improved compressive stress-strain behaviour when compared to those without the addition of steel fibers. This shows that addition of steel fibers to concrete mixtures will improve the stress-strain behaviour considerably. From the observed results for young's modulus on the cylinders, the highest young's modulus value was achieved for SFLWAC3 manufactured with $60 \%$ sintered fly ash aggregates without steel fibers. While the control concrete exhibits the lowest young's modulus value of $20.18 \mathrm{GPa}$, the average young's modulus value of SFLWAC3 $28 \%$ increased. 
Table 6. Elastic modulus of SFLWAC mixtures

\begin{tabular}{|c|c|c|}
\hline Mix ID & Young's modulus ${ }^{\text {a }}(\mathrm{GPa})$ & Relative Young's modulus (\%) \\
\hline CC & 20.18 & 100 \\
\hline SFLWAC1 & 32.89 & 163 \\
\hline SFLWAC2 & 41.21 & 204 \\
\hline SFLWAC3 & 46.06 & 228 \\
\hline SFLWAC4 & 41.55 & 205 \\
\hline SFLWAC5 & 33.23 & 164 \\
\hline SFLWAC6 & 32.25 & 159 \\
\hline SFLWAC7 & 45.74 & 226 \\
\hline
\end{tabular}

\subsection{STRUCTURAL EFFICIENCY}

In lightweight concrete or mortars, the compressive strength is firmly connected with their density; compressive strength diminishes with a reduction in density. Particularly when connected in longspan or tall structures, the density and strength of lightweight concrete is pivotal to achieve a high strength while holding low density. This connection is normally researched utilizing the alleged structural efficiency, which is calculated from the proportion of compressive strength at 28 days to density, as

$$
s t_{\eta}=\frac{f_{c k}}{\rho}
$$

Where, $s t_{\eta}$ is the structural efficiency $(\mathrm{Nm} / \mathrm{kg}), f_{c k}$ is the compressive strength at 28 days $(\mathrm{MPa})$, and $\rho$ is the actual density of the sample $\left(\mathrm{kg} / \mathrm{m}^{3}\right)$.

Table7. Compressive strength, density, and calculated structural efficiency of the SFLWACs

\begin{tabular}{|c|c|c|c|}
\hline Mix ID & $\begin{array}{c}\text { Compressive strength at 28 days } \\
(\mathrm{MPa})\end{array}$ & $\begin{array}{c}\text { Dry Density at } \\
28 \text { days }\left(\mathrm{kg} / \mathrm{m}^{3}\right)\end{array}$ & $\begin{array}{c}\text { Structural efficiency } \\
(\mathrm{Nm} / \mathrm{kg})\end{array}$ \\
\hline CC & 32.1 & 2487 & 12,907 \\
\hline SFLWAC1 & 34.40 & 2420 & 14,215 \\
\hline SFLWAC2 & 40.93 & 2300 & 17,796 \\
\hline SFLWAC3 & 35.73 & 2213 & 16,146 \\
\hline SFLWAC4 & 33.5 & 2571 & 13,030 \\
\hline SFLWAC5 & 35.3 & 2420 & 14,587 \\
\hline SFLWAC6 & 42.6 & 2303 & 18,498 \\
\hline SFLWAC7 & 39.2 & 2253 & 17,399 \\
\hline
\end{tabular}

The structural efficiencies as well as the densities of these mixes and their appropriate compressive strengths at 28 days are listed in Table 6. The structural efficiency of the control mixture was 12,907 $\mathrm{Nm} / \mathrm{kg}$. Mixtures SFLWAC1, SFLWAC2, and SFLWAC3 indicate the structural efficiency results 
of without the addition of steel fibers. Among these, SFLWAC2 shows the best results. This indicates the optimum percentage of sintered fly ash aggregate for concrete. Mixtures SFLWAC5, SFLWAC6, and SFLWAC7 indicate the structural efficiency results of SFLWAC with steel fibers. SFLWAC6 shows the highest structural efficiency among all the mixtures. This indicates that the structural efficiency is in indirect proportion to the density. Mixture SFLWAC6 shows better structural efficiency due to a reduction in the permeability of concrete and the addition of steel fibers.

\section{Conclusions}

Based on the present experimental work conducted on sintered fly ash aggregates, the following conclusions are drawn:

1. Crushing and impact strength of sintered fly ash aggregates were found to be satisfactory as required for use for lightweight structural applications.

2. The slump of the mixtures increased when the proportion of SFLWA content increased.

3. The unit weight of the concrete mixtures increased in the concrete containing steel fibers.

4. Reduction in mechanical properties was reported for the higher substitution of sintered fly ash aggregate.

5. Usage of steel fibers increases the compressive strength of SFLWAC mixtures about 4 $32 \%$.

6. The split tensile and flexural strength of SFLWAC mixtures decreased when the sintered fly ash aggregate content increased beyond $20 \%$. This decrease in strength can be overcome by usage of a higher aspect ratio in the fibers in concrete.

7. The addition of SFLWA into concrete mixtures increases the elastic modulus; this may be due to the reduction in the permeability of the concrete matrix. The addition of steel fibers increase the elastic modulus of the SFLWACs mixtures.

8. Comparing to SFLWAC3, SFLWAC7 shows a decreased elastic modulus. This is caused by the concrete matrix having a higher amount of SFLWA and no adverse effects on the steel fibers.

9. The structural efficiency shows that sintered fly ash aggregates containing concrete mixtures are suitable for high-rise constructions. 


\section{REFERENCES}

1. M.H. Zhang, O.E. Gjorv, "Characteristics of lightweight aggregates for high-strength concrete”ACI Mater. J.,Vol.8, 1991, March-April.pp.150.

2. Neville AM. Properties of concrete, John Wiley \&sons, NY, USA, 1996

3. Ramamurthy K, Harikrishnan K, "Influence of binders on properties of sintered fly ash aggregates" Cement and Concrete Composites, Vol.28, 2006, pp.33-8.

4. Erhan Guneyisi, Mehmet Gesoglu, Ozgur Pursunlu, Kasim Mermerdas, “ Durability aspect of concretes composed of cold bonded and sintered fly ash lightweight aggregates Composites: Part B 53, 2013, pp.258-266

5. BozkurtNusret\&YaziciogluSalih,“ Strength and capillary water absorption of lightweight concreteunder different curing conditions” Indian J Eng Mater sci, Vol.17, 2010,pp.145-51.

6. Gomathi P \&Sivakumar A, “Accelerated curing effects on the mechanical performance of cold bonded and sintered fly ash aggregate concrete" Construction and Building Materials, Vol.77, 2015, pp.276-287.

7. Al-Khaiyat H \&Haque N, "Strength and durability of lightweight concrete in hot marine exposure conditions" Master struct, Vol.32, 1999, pp.533.8

8. MehtapkPK \& MonteiroPJM. Concrete; microstructure, properties and materials, 3rd edition.McGraw-Hill, New york, 2006.

9. IS 12269:1989, Specification for Ordinary Portland cement 53 grade, Bureau of Indian Standards, New Delhi. 12.

10. IS4031:1996(Part1), Determination of Fineness by dry sieve, Bureau of Indian Standards, New Delhi-12.

11. IS 2386:1963(Part-IV), Methods of test for aggregates for concrete, Bureau of Indian Standards, New Delhi-12.

12. IS 10262: 2009, Concrete Mix Proportioning - Guidelines, Bureau of Indian Standards, New Delhi-12.

13. IS516:1959, Method of Tests for Strength of Concrete,Bureau of Indian Standards, New Delhi-12.

14. ASTM C459, Standard Test Method for Static Modulus of Elasticity and Poisson's Ratio of Concrete in Compression.

15. IS:1199:1959, Method of sampling ana analysis of Concrete,Bureau of Indian Standards,NewDelhi-12. 


\section{LIST OF FIGURES AND TABLES:}

Fig.1. Sintered Fly ash aggregate

Rys.1. Kruszywo ze spiekanego popiołu lotnego

Tab.1. The sieve analysis results of the natural and sintered fly ash aggregates

Tab.1. Wyniki analizy sitowej kruszyw z naturalnego i spiekanego popiołu lotnego

Tab.2. Physical and mechanical properties of natural and sintered fly ash aggregates

Tab.2. Właściwości fizyczne i mechaniczne kruszyw z naturalnego i spiekanego popiołu lotnego

Tab.3. Mix Proportions

Tab.3. Proporcje mieszania

Tab.4. Slump value and unit weight of concrete mixtures

Tab.4. Wartość spadku i masa jednostkowa mieszanin betonowych

Tab.5. Mechanical Properties of SFLWAC mixtures

Tab.5. Właściwości mechaniczne mieszanin SFLWAC

Tab.6. Elastic Modulus of SFLWAC mixtures

Tab.6. Moduł sprężystości mieszanin SFLWAC

Tab.7. Compressive strength, density and calculated structural efficiency of the SFLWAC

Tab.7. Wytrzymałość na ściskanie, gęstość i obliczona efektywność konstrukcyjna SFLWAC

Received 19.07.2017

Revised 16.03.2018 


\section{BADANIE WLAŚCIWOŚCI MECHANICZNYCH BETONU LEKKIEGO KRUSZYWOWEGO ZE SPIEKANEGO POPIOLU LOTNEGO (SFLWAC) Z WLÓKNEM STALOWYM}

Slowa kluczowe: Kruszywa ze spiekanego popiołu lotnego, spadek, wytrzymałość na ściskanie, wytrzymałość na rozciąganie, wytrzymałość na zginanie, moduł sprężystości i efektywność konstrukcyjna.

\section{PODSUMOWANIE:}

Kruszywa z popiołu lotnego mogą być wytwarzane zarówno z kruszyw wiążących na zimno jak i z kruszyw spiekanych. Naukowcy koncentrują się wyłącznie na wytwarzaniu kruszyw i bezpośrednim wykorzystaniu gruboziarnistych kruszyw w betonie. Kruszywa spiekane wykazują się lepszą wydajnością w porównaniu do kruszyw wiążących na zimno. Kilku naukowców przeprowadziło badanie poświęcone naturalnym kruszywom oraz spiekanym kruszywom. W niniejszym badaniu, kruszywa ze spiekanego popiołu lotnego zostały częściowo zastąpione naturalnymi kruszywami w gatunku betonu M30, w celu zbadania właściwości mechanicznych i sprężystych. To pokazuje, że kruszywo może być wykorzystywane do zastosowań konstrukcyjnych. Włączenie włókien stalowych do tej betonowej matrycy miało na celu porównanie zachowania na świeżym i utwardzonym podłożu. W pracy skupiono się na przydatności kruszyw ze spiekanego popiołu lotnego w betonie. Początkowo kruszywa ze spiekanego popiołu lotnego zostały poddane badaniu pod kątem właściwości fizycznych, takich jak gęstość w stanie suchym, ciężar właściwy, wchłanianie wody, udatność i wytrzymałość na zgniatanie dla przydatności kruszywa do mieszania z betonem. Miało to również na celu sprawdzenie wytrzymałości kruszyw ze spiekanego popiołu lotnego w betonie. Opracowano docelową wytrzymałość na ściskanie na poziomie $30 \mathrm{~N} / \mathrm{mm} 2$ i otrzymano próbne mieszaniny w oparciu o IS 10262: 2009. Te próbne mieszaniny zostały następnie poddane badaniu pod kątem 20\%, 40\% i 60\% częściowej wymiany na naturalne gruboziarniste kruszywo, a następnie wybrano najlepszą mieszaninę na podstawie wytrzymałości na ściskanie próbek betonu. Wyniki pokazują, że $40 \%$ wymiana kruszyw ze spiekanego popiołu lotnego okazała się lepszym rozwiązaniem w porównaniu do innych mieszanin. Mieszaniny te zostały następnie dokładniej zbadane w odniesieniu do różnych proporcji włókien stalowych w mieszaninach betonowych, dla współczynnika kształtu wynoszącego 55 i objętości wynoszącej 0,5\% w mieszaninach betonowych. Następnie do mieszanin dodano włókna szklane, co powoduje zwiększenie ich wytrzymałości i właściwości wiążących w mieszaninach betonowych. 